\title{
PENGARUH PENERAPAN MEDIA PEMBELAJARAN LECTORA INSPIRE TERHADAP MINAT BELAJAR FIQIH
}

\author{
Istaqul Kahfi \\ UIN K.H. Achamd Siddiq Jember \\ gantengtaqul@gmail.com \\ Moh. Sutomo \\ UIN K.H. Achamd Siddiq Jember \\ sutomompd1971@gmail.com \\ Moh. Sahlan \\ UIN K.H. Achamd Siddiq Jember \\ moh_sah94@yahoo.com
}

\begin{abstract}
Abstrak
Penelitian ini dilatar belakangi oleh rendahnya minat belajar peserta didik dalam mengikuti kegiatan pembelajaran. Tujuan penelitian ini adalah untuk mengetahui apakah terdapat pengaruh penerapan media pembelajaran Lectora Inspire terhadap minat belajar fiqih pada siswa kelas X di MA Nurus Sholah Yosowilangun, Lumajang. Adapun pendekatan yang penulis gunakan yaitu pendekatan kuantitatif dengan jenis penelitian survei. Teknik pengumpulan data menggunakan angket/kuesioner, observasi, dan dokumentasi. Kuesioner sebagai instrumen penelitian dilakukan untuk memperoleh data X dan Y dan kemudian dianalisis dengan teknik analisis regresi satu prediktor dengan skor deviasi. Sementara itu, metode yang digunakan dalam penelitian ini adalah eksperimen. Eksperimen yang digunakan adalah Quasi Eksperimental Design. Populasi dalam penelitian ini adalah siswa kelas $\mathrm{X}$ yang berjumlah36 siswa dan kemudian diambil 2 kelas sebagai sampel.Teknik analisis data menggunakan rumus 'T-test'. Perhitungan yang digunakan adalah analisis perbandingan skor post test dari kelas kontrol dengan kelas eksprimen. Harga signifikansi perbandingan post test sebesar 0,000 < 0,05 , yang berarti hal tersebut menunjukkan bahwa ada perbedaan yang signifikan antara skor post test kelas kontrol dengan dengan skor post test kelas eksperimen. bahwa penerapan media pembelajaran aplikasi Lectora Inspire berpengaruh secara signifikan terhadap minat belajar fiqih pada siswa kelas X di MA Nurus Sholah Yosowilangun.
\end{abstract}

Kata kunci: media pembelajaran,lectora inspire, minat belajar, Fiqih

\begin{abstract}
This research is motivated by the low interest in learning of students in participating in learning activities. The purpose of this study was to determine whether there was an effect of the application of the learning media Lectora Inspire on interest in learning figh in class $X$ students at MA Nurus Sholah Yosowilangun, Lumajang. The approach that the author uses is a quantitative approach with the type of survey research. Data collection techniques used a questionnaire/questionnaire, observation, and documentation. Questionnaire as a research instrument was conducted to obtain $X$ and $Y$ data and then analyzed using one predictor regression analysis technique with a deviation score. Meanwhile, the method used in this research is experimental. The experiment used is Quasi Experimental Design. The population in this study were
\end{abstract}




\section{AL- ADABIYAH: JurnalPendidikan Agama Islam}

students of class $X$ totaling 36 students and then 2 classes were taken as samples. The data analysis technique uses the 'T-test' formula. The calculation used is a comparative analysis of post-test scores from the control class with the experimental class. The significance value of the post-test comparison is $0.000<0.05$, which means that it indicates that there is a significant difference between the post-test scores of the control class and the post-test scores of the experimental class. that the application of the Lectora Inspire application learning media has a significant effect on interest in learning figh in class X students at MA Nurus Sholah Yosowilangun.

Keywords: learning media, lectora inspire, interest in learning, Fiqh

\section{Pendahuluan}

Dalam proses belajar mengajar kehadiran media mempunyai arti penting,karena dalam kegiatan tersebut,bahan materi ajaryang akan disampaikan dapat dibantu dengan menghadirkan media sebagai penunjang. Media dapat mewakili apa yang kurang mampu guru ucapkan melalui kata-kata atau kalimat tertentu. Bahkan keabstrakan bahan dapat dikonkritkan dengan kehadiran media (Samani, 2004: 9).

Oleh karena itu, seorang guru dituntut agar mengembangkan metode pembelajaran dengan memanfaatkan media pembelajaran yang ada di sekolah. Dengan menggunakan media proses pembelajaranakan lebih efektif, karena bukan hanya guru yang aktif melainkan siswa juga ikutdilibatkan sehingga timbul timbal baliknya, dengan seperti itu akan dapat meningkatkan minat belajar siswa dalam setiap mata pelajaran yang diajarkan.

Seperti halnya dalam pembelajaran mata pelajaran fiqih yang identik dengan penyampaian monoton secara ceramah oleh guru, membuat siswa menjadi jenuh, bosan dan kurang memiliki minat belajar, hal tersebut terbukti berdasarkan hasil survey pra penelitian dengan membagikan 20 butir kuesioner yang di lakukan di MA Nurus Sholah Yosowilangun, bahwa dari 36 siswa kelas X terdapat 24\% siswa yang minat pelajaran fiqih, 26\% siswa ragu-ragu, dan $50 \%$ siswa tidak minat pelajaran fiqih. Hal ini disebabkan beberapa faktor, di antaranya terdapat beberapa siswa yang tidak faham materi fiqih dikarenakan media yang digunakan kurang memfasilitasi siswa dalam pemahaman materi sehingga media yang digunakan tidak bervariatif dan juga monoton.

Permasalahan tersebut tentu saja dapat di atasi oleh seorang guru dengan beberapa upaya, salah satunya dengan mengambangkan media pembelajaran yang memanfaatkan teknologi pendidikan Multimedia. Pembuatan media pembelajaran berbasis multimedia dapat menggunakan berbagai macam perangkat lunak, salah satunya Lectora Inspire. Lectora Inspire merupakan software yang dapat digunakan untuk mengembangkan konten digital materi ajar dan materi uji berbentuk 


\section{AL- ADABIYAH: JurnalPendidikan Agama Islam}

multimedia dinamis, mudah (user friendly) dan berkualitas tanpa membutuhkan keahlian desain seni dan grafis serta pemrograman yang tinggi untuk mengikuti dinamika perubahan sistem belajar mengajar (Basman, 2017, hal. 8). Pada MA Nurus Sholah terdapat pembelajaran fiqih menggunakan media multimedia berbentuk Lectora Inspire.hipotesis statistik dari penelitian ini dapat dibedakan menjadi dua jenis, yaitu sebagai berikut:

$\mathrm{H}_{\mathrm{i}}$ : terdapat pengaruh penerapan media pembelajaran Lectora Inspire terhadap minat belajar fiqih pada siswa kelas X di MA Nurus Sholah Yosowilangun Lumajang.

$\mathrm{H}_{0}$ : tidak terdapat pengaruh penerapan media pembelajaran Lectora Inspire terhadap minat belajar fiqih pada siswa kelas X di MA Nurus Sholah Yosowilangun Lumajang.

Dari paparan dan penjelasan diatas maka dapat kita ketahui tujuan dari penelitian untuk mengetahui pengaruh penerapan media pembelajaran Lectora Inspire terhadap minat belajar fiqih pada siswa kelas X di MA Nurus Sholah Yosowilangun, Lumajang.

\section{Tinjauan Literatur}

\section{Media Pembelajaran Lectora Inspire}

Kata media berasal dari bahasa Latin medius yang secara harfiah berarti 'tengah' pengantar' atau perantara. Dalam bahasa Arab, media adalah perantara ( وَسَاِيُ ) atau pengantar pesan dari pengirim kepada penerima pesan. Media apabila dipahami secara garis besar adalah manusia, materi, atau kejadian yang membangun kondisi yang membuat siswa mampu mampu memperoleh pengetahuan, keterampilan, atau sikap (Arsyad, 2009: 8). Media juga diartikan sebagai medium sebagai perantara yang mengantar informasi antara sumber dan penerima. Jadi televisi, film, foto, radio, rekaman, audio, gambar yang diproyeksikan, bahan-bahan cetakan, dan sejenisnya adalah media komunikasi.

Sedangkan Lectora Inspire adalah alat pengembangan belajar elektronik (elearning), juga dikenal sebagai perangkat lunak authoring, dikembangkan oleh Trivantis Corporation (Mas'ud, 2012: 20). Lectora merupakan software yang sudah dirancang dari awal untuk kebutuhan e-learning. Lectora dapat digunakan sebagai kebutuhan pembelajaran baik secara online maupun offline yang dibuat dengan cepat dan mudah. Lectora dapat digunakan dengan 


\section{AL- ADABIYAH: JurnalPendidikan Agama Islam}

menggabungkan flash, merekam video menggabungkan flash, merekam video, menggabungkan gambar, dan screen capture (Basman, 2017: 5). Dari berbagai pendapat diatas, maka dapat disimpulkan bahwa, media pembelajaran Lectora Inspire adalah program yang efektif dalam membuat media pembelajaran dan merupakan software pengembangan belajar elektronik (e-learning) yang relatif mudah diaplikasikan atau diterapkan karena tidak memerlukan pemahaman bahasa program yang canggih (Sudiman, 2012: 36).

\section{Minat Belajar}

Minat merupakan dorongan dalam diri seseorang atau faktor yang menimbulkan ketertarikan atau perhatian secara selektif yang menyebabkan dipilihnya suatu objek atau kegiatan yang menguntungkan, menyenangkan yang lama kelamaan akan mendatangkan kepuasan. Minat dapat diartikan sebagai suatu kesukaan, kegemaran atau kesenangan akan sesuatu. Adapun menurut Sardiman, minat adalah suatu kondisi yang terjadi apabila seseorang melihat ciriciri atau arti sementara situasi yang dihubungkan dengan keinginan-keinginan atau kebutuhan-kebutuhan sendiri (Susanto, 2014: 47).

Sedangkan belajar merupakan proses usaha yang dilakukan seseorang untuk memperoleh suatu perubahan tingkah laku yang baru secara keseluruhan, sebagai hasil pengalamannya sendiri dalam interaksi dengan lingkungannya dengan berbagai macam kompetensi, keterampilan dan sikap. Salah satu pertanda bahwa seorang telah belajar adalah perubahan tingkah laku dalam dirinya. Perubahan tingkah laku tersebut menyangkut baik perubahan yang bersifat pengetahuan (kognitif), keterampilan (psikomotor) dan yang menyangkut nilai-nilai dan sikap (afektif) (Sudiman, 2012: 36).

Maka dapat diketahui pengertian minat belajar sendiri adalah keinginan yang besar terhadap pembelajaran dan terdorong untuk lebih memperhatikan proses pembelajaran sehingga terciptalah kemampuan atau keterampilan untuk dapat menyelesaikan masalah-masalah yang dihadapinya. Dalam kaitannya dengan belajar, minat belajar erat hubungannya dengan kepribadian, motivasi, ekspresi dan konsep diri atau identifikasi, faktor keturunan dan pengaruh eskternal atau lingkungan. Dalam praktiknya, minat atau dorongan dalam diri memiliki kaitan dengan peluang atau hambatan siswa dalam mengekspesikan potensi atau kreativitas dirinya sebagai perwujudan dari minat spesifik yang dimiliki (Djamarah, 2011: 166). 


\section{AL- ADABIYAH: JurnalPendidikan Agama Islam}

\section{Pembelajaran Fiqih}

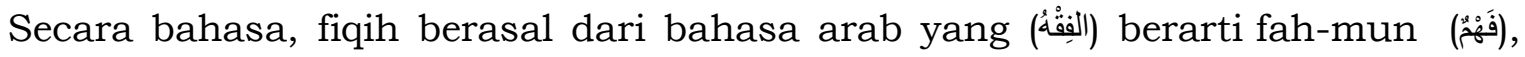
yang artinya pemahaman mendalam yang memerlukan pengerahan akal pikiran. Sedangkan menurut istilah yang digunakan para ahli Fiqih(Fuqaha), Fiqih merupakan ilmu pengetahuan yang membicarakan atau membahas tentang hukum-hukum Islam yang bersumber pada Al-Qur'an,As-Sunnah dan dari dalildalil terperinci.

Pembelajaran fiqih adalah sebuah proses belajar untuk membekali siswa agar dapat mengetahui dan memahami pokok-pokok hukum Islam secara terperinci dan menyeluruh, baik berupa dalil aqli maupun dalil naqli (Syafe'i, 2015: 17). Tujuan pembelajaran fiqih untuk mengetahui dan memahami prinsip-prinsip, kaidahkaidah dan tata cara pelaksanaan hukum Islam baik yang menyangkut aspek ibadah maupun muamalah untuk dijadikan pedoman hidup dalam kehidupan pribadi dan sosial (Syafri, 2015: 22). Dalam penelitian ini penulis akan lebih memfokuskan untuk melakukan penelitian dengan menggunakan materi sholat jenazah.

\section{Metode}

Metode penelitian ini yang dipilih adalah metode penelitian kuantitatif dengan jenis pendekatan Quasi Experimental Design. Bentuk desain ksperimen ini merupakan pengembangan dari true experimental design (Sugiono, 2017: 45). Populasi dalam penelitian ini adalah seluruh siswa kelas X MA Nurus Sholah dengan jumlah keseluruhan 36 siswa. Dalam penelitian ini, peneliti hanya mengambil sampel dari kelas X A sebagai kelas eksperimen dan X B sebagai kelas kontrol.

Teknik pengumpulan data yang digunakan dalam penelitian ini yaitu, observasi, angket dan kuesioner serta dokumentasi. Dalam penelitian ini, instrumen yang digunakan adalah lembar angket atau kuesioner untuk mengukur minat belajar. Uji coba instrumen penelitian terdiri dari, ujivaliditas instrument, penelitian ini menggunakan angket, validitas ini dapat dihitung dengan koefisien korelasi menggunakan product moment yang dilakukan oleh Pearson dengan angka kasar (Widiyanto, 2014: 86). 


\section{AL- ADABIYAH: JurnalPendidikan Agama Islam}

$$
=\quad \frac{n \sum X Y-\left(\sum X Y\right)\left(\sum\right.}{\sqrt{\left(n \sum X^{2}-\left(\sum X\right)^{2}\left(n \sum Y\right.\right.}}
$$

Keterangan :

$$
=\text { koefisien validitas } X \text { dan } Y
$$

$$
\begin{gathered}
\qquad \mathrm{XY}=\text { Jumlah perkalian } X \text { dan } Y \\
X=\text { skor masing-masing butir soal } \\
Y=\text { skor total butor soal } \\
N=\text { jumlah peserta test }
\end{gathered}
$$

Uji instrumen yang dilakukan juga menggunakan uji reliabilitas. Reliabilitas merupakan penerjemahan dari kata realiability yang mempunyai asal reli dan ability. Pengukuran yang memiliki reliabilitas tinggi disebut sebagai pengukuran yang reliabel. Dengan rumus Alpha Cronbach's :

$$
r_{11}=\left[\frac{k}{k-1}\right]\left[1-\frac{\sum \sigma b^{2}}{\sigma t^{2}}\right]
$$

Keterangan:

$$
\begin{array}{ll}
\mathrm{r}_{11} & =\text { Reliabilitasinstrumen } \\
\mathrm{k} & =\text { banyaknya itempertanyaan } \\
\sum \sigma & =\text { Jumlah varianbutir } \\
\sigma & =\text { Variantotal }
\end{array}
$$

Dalam penelitian kuantitatif, teknik analisis yang digunakan sudah jelas, yaitu diarahkan untuk menjawab rumusan masalah atau menguji hipotesis yang telah dirumuskan dalam rumusan masalah. Dilihat dari metodenya, ada dua jenis statistik yang dipilih, yaitu statistik deskriptif dan inferensial. Dalam statistik inferensial terdapat statistik parametrik dan non parametrik. Disini peneliti menggunakan teknik analisis data statistik parametik dengan analisis Uji T dengan programSPSS. Adapun langkah-langkah untuk melakukan uji T dua kelompok subjek adalah melakukan uji normalitasdata, melakukan ujihomogenitas, Melakukan uji hipotesis.

\section{Hasil dan Diskusi}

Dalam penelitian ini penulis mengamati satu pokok pembahasan yaitu pengaruh media pembelajaran berbasis lectora terhadap minat belajar siswa mata pelajaran fiqih kelas X di MA Nurus Sholah. Penelitian ini mengambil data siswa 


\section{AL- ADABIYAH: JurnalPendidikan Agama Islam}

dan sebaran quesioner tentang minat belajar pada pelajaran fiqih kelas $\mathrm{X}$ MA Nurus Sholah sebanyak 20 butir. Pengambilan sampel sebanyak 36 siswa, yaitu terdiri dari 18 siswa kelas eksperimen dengan diberi perlakuan dengan menggunakan media aplikasi Lectora Inspire dan 18 siswa kelas kontrol dengan menerapkan media konvensional.

Sebelum penelitian dilakukan, peneliti terlebih dahulu melakukan uji instrumen dikelas XA dengan jumlah peserta didik 20 orang.Berdasarkan jumlah uji coba instrumen kuesioner tentang minat minat belajar siswa pada pelajaran fiqih sebanyak 20 butir quesioner dan terpilih 20 kuisioner yang dinyatakan layak untuk digunakan dalan penelitian. Instrumen penelitian yang digunakan dalam penelitian ini adalah instrumen untuk mengukur minat belajar siswa pada pelajaran fiqih materi pengurusan jenazah.

Penelitian mengumpulkan untuk pengujian hipotesis 4 kali pertemuan kelas ekperimen 1 dan $4 \mathrm{x}$ pertemuan kelas kontrol. Padapertemuan pertama baik kelas eksperimen maupun control dilakukan pretestse belum diberikan materi sholat jenazah. Pada pertemuan kedua, ketiga dan keempat mengajar dengan menggunakan media pembelajaran aplikasi Lectora Inspire untuk kelas eksperimen, dan mengajar dengan menggunakan model pembelajaran konvensional untuk kelas kontrol. Pada pertemuan terakhir peneliti memberikan posttest terhadap dua kelas, quisioner pretest danposttest tersebut merupakan instrumen yang sudah diuji validitas dan reliabilitasnya.

Dalam kegiatan penelitian, model pembelajaran dirancang dalam rencana pelaksanaan pembelajaran (RPP) untuk dua jam pelajaran (2x35 menit), dan tigakali pertemuan. RPP ini memuat pendahuluan, kegiatan inti, dan kegiatan penutup dirancang sedemikian rupa. Penelitian ini mempunyai satu variabel bebas yaitu media pembelajaran Lectora Inspire dan satu variabel terikat yaitu minat belajar peserta didik. Penelitian ini dilakukan pada peserta didik kelasX MA Nurus Sholah sebagai populasi, dan sampel yang diambil dalam penelitian ini adalah kelas X A sebagai kelas eksperimen dengan jumlah 18 peserta didik,dan kelas X B sebagai kelas kontrol dengan jumlah 18 peserta didik. Disini penelitilah yang mengajar secara langsung pada kedua kelas tersebut antara kelas kontrol dan eksperimen, dan guru mapel fiqih MA Nurus Sholah sebagai pengamat kegiatan belajar mengajar.

Pada kelas eksperimen diterapkan media pembelajaran Lectora Inspire proses pembelajaran yang sebelumnya tidak aktif, tidak menarik dan juga 


\section{AL- ADABIYAH: JurnalPendidikan Agama Islam}

membosankan, seketika berubah menjadi pembelajaran yang aktif, efektif, menarik dan juga menyenangkan, hal ini tentu saja dapat membantu peserta didik untuk meningkatkan minat belajar mereka itu sendiri. Selain itu proses pembelajaran di kelas juga mampu memberikan pengaruh bagi peserta didik, karena lebih menumbuhkan minat belajar siswa dalam mengikuti kegiatan pembelajaran sehingga dapat memberikan hasil belajar yang maksimal.

Sedangkan situasi pembelajaran di kelas kontrol berbeda dengan kelas eksperimen, yakni pada tahap kegiatan inti pembelajaran. Kelas kontrol menggunakan model pembelajaran konvensional dimana proses pembelajarannya berpusat pada guru, di sini terlebih dahulu menjelaskan materi yang diajarkan sementara peserta didik mendengarkan dan memperhatikan penjelasan yang disampaikan oleh pendidik sehingga akan timbul rasabosan pada siswa, akibatya siswa hanya tidur-tiduran, mengobrol dengan teman sebangku, sehingga pembelajaran tidak efektif. Setelah pendidik menjelaskan materi dilanjutkan dengan pemberian soal-soal latihan yang harus dikerjakan pada peserta didik dalam waktu yang telah ditentukan.

Diakhir pembelajaran, pendidik memberikan evaluasi dan dilanjutkan dengan menutup pembelajaran. Dengan demikian peserta didik kurang aktif dalam mengemukakan gagasannya sehingga peserta didik kurang mengembangkan kemampuan literasi sains dalam menyelesaikan soal.Hipotesis dalam penelitian ini yaitu Penggunaan Media Pembelajaran Audio visual dapat meningkatkan minat belajarpeserta didik pada mata pelajaran fiqih. Untuk mengetahui benar atau tidaknya hipotesis tersebut, dilakukan uji $\mathrm{T}$.

Hasil penelitian ini menunjukkan bahwa penerapan aplikasi Lectora Inspire berpengaruh terhadap minat belajar siswa. Hal tersebut dapat dilihat dari hasil perbandingan pre test, perbanding an kenaikan skor pretest-posttest, dan perbandingan post test. Hasil perbandingan pre test berpengaruh terhadap langkah selanjutnya yaitu perbandingan post test atau selisih skor pre test dengan post test.

Hasil signifikansi perbandingan pretest yaitu $0,328>0,05$, berarti tidak ada perbedaan titik pijak antara kelas kontrol dengan kelas eksperimen.Dengan demikian perhitungan yang digunakan adalah analisis perbandingan skor post test dari kelas kontrol dengan kelas eksprimen. Harga signifikansi perbandingan post test sebesar $0,000<0,05$, yang berarti ada perbedaan yang signifikan antara skor post test kelas kontrol dengan dengan skor post test kelas eksperimen. 


\section{AL- ADABIYAH: JurnalPendidikan Agama Islam}

\section{Kesimpulan}

Minat belajar siswa pada kelas eksperimen lebih tinggi dibandingkan minat belajar siswa pada kelas kontrol pada pelajaran fiqih kelas X di MA Nurus Sholah Yosowilangun. Hal ini ditunjukkan dari hasil rata-rata nilai pre test dan post test pada kelas eksperimen dan kelas kontrol. Rata-rata nilai pre test kelas eksperimen adalah 59,83 sedangkan rata-rata nilai pre test kelas kontrol adalah 60,44. Ratarata nilai post test kelas eksperimen adalah 86,89 sedangkan rata-rata nilai post test kelas kontrol adalah 63,56.

Perhitungan yang digunakan adalah analisis perbandingan skor post test dari kelas kontrol dengan kelas eksprimen. Harga signifikansi perbandingan post test sebesar $0,000<0,05$, hal tersebut menunjukkan bahwa ada perbedaan yang signifikan antara skor post test kelas kontrol dengan dengan skor post test kelas eksperimen. Sehingga, dapat disimpulkan bahwa penerapan media pembelajaran aplikasi Lectora Inspire berpengaruh secara signifikan terhadap minat belajar fiqih pada siswa kelas X di MA Nurus Sholah Yosowilangun, Lumajang.

\section{Referensi}

Arsyad, Azhar. (2017). Media Pembelajaran, Revisi. Jakarta: PT Raja Grafindo Persada.

Basman, Tompo.(2017). Membuat Aplikasi Dan Media Pembelajaran Interaktif Dengan Lectora Inspire 16. Yogyakarta: Ikatan Guru Indonesia.

Samani. (2014). Belajar Dan Pembelajaran. Bandung: PT Remaja Rosdakarya.

Sugiyono. (2016). Metode Penelitian Kuantitatif, Kualitatif, dan R\&D. Bandung: Alfabeta.

Mas'ud, Muhammad. (2012). Membuat Multimedia Pembelajaran dengan Lectora. Yogyakarta: Pustaka Shonif.

Sudiman, Arief S. (2012). Media Pendidikan, Pengertian, Pengembangan, dan Pemanfaatannya. Depok: Raja Wali Pers.

Susanto, Ahmad. (2014). Teori Belajar dan Pembelajaran di Sekolah Dasar. Jakarta: Kencana.

Syafe'i, Rachmat. (2015). Ilmu Ushul Fiqih. Bandung: CV Pustaka Setia.

M. Noor, Syafri. (2015). Pengantar Fiqih Jenazah. Yogyakarta: PT Pustaka Setia.

Djamarah, Syaiful Bahri. (2011). Psikologi Belajar. Jakarta : Rineka Cipta.

Widiyanto, Joko. (2014). Evaluasi Pembelajaran . Yogyakarta: Pustaka Insan Madani. 